\title{
Tracking animals in freshwater with electronic tags: past, present and future
}

\author{
Steven J Cooke ${ }^{1 *}$, Jonathan D Midwood ${ }^{1}$, Jason D Thiem ${ }^{1}$, Peter Klimley ${ }^{2}$, Martyn C Lucas ${ }^{3}$, Eva B Thorstad ${ }^{4}$, \\ John Eiler ${ }^{5}$, Chris Holbrook ${ }^{6}$ and Brendan C Ebner ${ }^{7}$
}

\begin{abstract}
Considerable technical developments over the past half century have enabled widespread application of electronic tags to the study of animals in the wild, including in freshwater environments. We review the constraints associated with freshwater telemetry and biologging and the technical developments relevant to their use. Technical constraints for tracking animals are often influenced by the characteristics of the animals being studied and the environment they inhabit. Collectively, they influence which and how technologies can be used and their relative effectiveness. Although radio telemetry has historically been the most commonly used technology in freshwater, passive integrated transponder (PIT) technology, acoustic telemetry and biologgers are becoming more popular. Most telemetry studies have focused on fish, although an increasing number have focused on other taxa, such as turtles, crustaceans and molluscs. Key technical developments for freshwater systems include: miniaturization of tags for tracking small-size life stages and species, fixed stations and coded tags for tracking large samples of animals over long distances and large temporal scales, inexpensive PIT systems that enable mass tagging to yield population- and community-level relevant sample sizes, incorporation of sensors into electronic tags, validation of tag attachment procedures with a focus on maintaining animal welfare, incorporation of different techniques (for example, genetics, stable isotopes) and peripheral technologies (for example, geographic information systems, hydroacoustics), development of novel analytical techniques, and extensive international collaboration. Innovations are still needed in tag miniaturization, data analysis and visualization, and in tracking animals over larger spatial scales (for example, pelagic areas of lakes) and in challenging environments (for example, large dynamic floodplain systems, under ice). There seems to be a particular need for adapting various global positioning system and satellite tagging approaches to freshwater. Electronic tagging provides a mechanism to collect detailed information from imperilled animals and species that have no direct economic value. Current and future advances will continue to improve our knowledge of the natural history of aquatic animals and ecological processes in freshwater ecosystems while facilitating evidence-based resource management and conservation.
\end{abstract}

Keywords: Acoustic telemetry, Biotelemetry, Coded tags, Passive integrated transponder, Radio telemetry

\section{Background}

Freshwater ecosystems around the globe face many threats and stressors [1-4], which have collectively led to dramatic reductions in freshwater biodiversity for a range of taxa [5,6]. Human activities are the primary source of these multiple stressors [7], such that Strayer and Dudgeon [8] eloquently describe what they call, 'the collision between humans and biodiversity in freshwater

\footnotetext{
* Correspondence: steven_cooke@carleton.ca

${ }^{1}$ Fish Ecology and Conservation Physiology Laboratory, Department of Biology, Carleton University, 1125 Colonel By Dr., Ottawa, ON, Canada Full list of author information is available at the end of the article
}

ecosystems.' Freshwater ecosystems provide vital resources for human beings (including water for drinking and irrigation, food, electricity and transport) and demands for freshwater have risen dramatically over the last century. The 125,000 species of freshwater animals that have been described represent 9.5\% of all known animal species on the planet (including one-third of all vertebrate species), even though fresh waters cover just $0.8 \%$ of the Earth's surface $[6,9]$, emphasizing that freshwater ecosystems are hotspots for biodiversity [8]. Unfortunately, owing to the proximity of human population centres to sources of freshwater and the associated
C Biomed Central

(c) 2013 Cooke et al.; licensee BioMed Central Ltd. This is an Open Access article distributed under the terms of the Creative Commons Attribution License (http://creativecommons.org/licenses/by/2.0), which permits unrestricted use, distribution, and reproduction in any medium, provided the original work is properly cited. 
demands on this resource, these systems are also hotspots for endangerment [6,8]. Given the immense ecosystem services provided by freshwater ecosystems [10], the importance of the animals that occupy these waters [11], and the livelihoods and well-being of the human beings that depend upon freshwater ecosystems $[12,13]$, there is a need to understand the biology of freshwater animals.

Basic life history information (including habitat requirements, migratory routes, foraging and reproductive sites, dispersal and home-range characteristics) is fundamental to understanding animals in relation to their environment, and when studied in the context of responses to human activities, provides resource managers and conservationists with practical knowledge to make informed decisions. However, studying macroscopic animals in freshwater ecosystems comes with its own unique set of challenges. Extreme depths, and high turbidity, discharge or current speed, ice cover, habitat complexity, and macrophyte density constrain the ability to view and collect freshwater animals. Additional constraints are imposed by the fact that some animals are small, cryptic or highly mobile. Although certain types of behaviour and physiology can be easily studied in captivity, relying solely on this type of study can be misleading since such studies fail to mimic natural scenarios involving complex interactions among multiple species and large-scale processes.

Today's field biologists have a variety of tools for studying animals in the natural environment, but given the challenges with visual observation in aquatic habitats, electronic tagging technology is regarded as one of the most effective means of studying the behaviour and ecophysiology of animals in their natural environment [14]. A variety of electronic tagging tools have been used in freshwater for the study of vertebrates and some of the larger invertebrates (summarized in [15-18]; See Table 1). Active telemetry tools that remotely transmit information between a transmitter and receiver, including radio and acoustic telemetry, and passive tools, such as passive integrated transponders (PIT tags), have been applied to a variety of freshwater taxa (Figure 1). Archival devices that record information from sensors (such as temperature, pressure, activity) that can be downloaded onto retrieving devices (also known as biologging) are also increasingly common in freshwater systems. These types of sensor have also been used extensively with active telemetry tools to enhance information collected regarding animal locations.

Despite the breadth of current telemetry technology, there are still many challenges associated with using electronic tags to study freshwater species. These range from the problem of attaching devices to animals, to the technical performance of the electronic technology, and methods of analyzing data. By considering historical developments that have led to our contemporary electronic tagging toolbox, it is possible to identify specific constraints and technical gaps that still exist and provide the foundation needed to foster future advances. To that end, the objective of this synthesis is to consider the past, present and future of electronic tagging and tracking techniques and technology. In order to narrow the scope of the review and focus on environments that share similar challenges, we focus on animals found in freshwater systems, including fish, mammals, reptiles, amphibians and invertebrates (mostly molluscs and arthropods) that are sufficiently large to be studied with electronic tags. We exclude all birds, since most associated tracking studies for birds focus on large-scale migrations. We include diadromous fish (but only their freshwater phase) as well as mammals that spend significant time in freshwater (for example, muskrats, manatees). This is not intended to be an exhaustive review. Rather the information presented represents the collective knowledge and perspectives of the authors with experience in using a variety of electronic tagging technologies, in different regions, and on different taxa.

\section{Key developments in freshwater tracking}

The creation and use of new technologies, methods and approaches is a gradual process. As such, many of the key developments are a culmination of innovation and discovery rather than a single discovery (or paper). Table 2 presents a list of key telemetry technologies used to study freshwater animals in the wild, and their associated strengths, weaknesses and typical applications.

\section{Reduction in tag size}

The progression of smaller and more efficient electronic components has been a major advance for aquatic telemetry, making it possible to reduce tag size substantially, and tag and track a wider range of species and life stages. Miniaturization has also made it possible to increase the capabilities of transmitters used on larger animals in terms of operating life, reception range and environmental and physiological sensors. Like many technologies, this has been a gradual process, and many of the advances in the 1970s set the stage for future work. Specific details in journal articles were often relegated to a few lines in the methods section, but the overall trend can be inferred from the steady increase in telemetry papers focused on habitat selection and movement patterns in smaller species and juvenile life stages of fish [63,64], and increasingly smaller nonfish taxa, such as some amphibians (black-bellied salamanders [65]) and invertebrates (crayfish [66]). Radio tags as small as $0.25 \mathrm{~g}$, acoustic tags as small as $0.30 \mathrm{~g}$, and PIT 
Table 1 Summary of the various technologies used for tracking animals in freshwater with a brief summary of strengths, limitations, and common applications

\begin{tabular}{|c|c|c|c|c|}
\hline Technology & $\begin{array}{l}\text { Summary of technology and } \\
\text { techniques }\end{array}$ & Strengths & Limitations & Applications \\
\hline \multirow[t]{3}{*}{$\begin{array}{l}\text { Acoustic } \\
\text { telemetry; } \\
\text { manual tracking }\end{array}$} & $\begin{array}{l}\text { Uses a transducer to convert } \\
\text { electrical energy to acoustic energy } \\
\text { that is detected by an underwater } \\
\text { hydrophone }\end{array}$ & Deep water (>20 m) & $\begin{array}{l}\text { Hydrophone must be } \\
\text { submerged in water }\end{array}$ & Some applications in FW \\
\hline & $\begin{array}{l}\text { Animals usually tracked by boat } \\
\text { using bearings and triangulation }\end{array}$ & $\begin{array}{l}\text { Can provide detailed } \\
\text { movement data } \\
\text { depending on tracking } \\
\text { method and conditions }\end{array}$ & $\begin{array}{l}\text { Ineffective in shallow or } \\
\text { turbulent water }\end{array}$ & $\begin{array}{l}\text { Mostly for fish, some use with } \\
\text { alligator, FW mammals and } \\
\text { elasmobranch }\end{array}$ \\
\hline & $\begin{array}{l}\text { Not suitable for transmitters with } \\
\text { long pulse interval (time between pulses) }\end{array}$ & & $\begin{array}{l}\text { Interference from } \\
\text { macrophytes and noise } \\
\text { (for example, boats, } \\
\text { entrained air) }\end{array}$ & \\
\hline \multirow[t]{3}{*}{$\begin{array}{l}\text { Acoustic } \\
\text { telemetry; fixed } \\
\text { stations }\end{array}$} & As above & $\begin{array}{l}\text { Can be deployed as } \\
\text { gates, grids, or arrays to } \\
\text { monitor animal } \\
\text { movements for long } \\
\text { periods, including under } \\
\text { ice }\end{array}$ & Generates large datasets & Widespread use in FW \\
\hline & $\begin{array}{l}\text { Autonomous or cabled } \\
\text { hydrophones and associated } \\
\text { loggers store time-stamped data } \\
\text { when tagged animals enter } \\
\text { reception zone }\end{array}$ & $\begin{array}{l}\text { Multiple stations can } \\
\text { provide precise two or } \\
\text { three-dimensional tracks } \\
\text { of animals }\end{array}$ & $\begin{array}{l}\text { Requires significant post- } \\
\text { processing and analytical } \\
\text { efforts (can be } \\
\text { challenging to recover } \\
\text { data with some systems) }\end{array}$ & $\begin{array}{l}\text { Mostly on fish, some use with } \\
\text { mammals that move between } \\
\text { marine and FW environments }\end{array}$ \\
\hline & & $\begin{array}{l}\text { Some systems provide } \\
\text { real-time data } \\
\text { transmission }\end{array}$ & $\begin{array}{l}\text { Interference from } \\
\text { macrophytes and noise } \\
\text { (for example, boats, } \\
\text { entrained air) }\end{array}$ & \\
\hline \multirow[t]{2}{*}{$\begin{array}{l}\text { Radio telemetry; } \\
\text { manual tracking }\end{array}$} & $\begin{array}{l}\text { Emit electromagnetic energy in } \\
\text { the radio frequency range (usually in } \\
\text { the } \mathrm{VHF} \text { band between } 30 \text { and } 300 \mathrm{MHz} \text { ) }\end{array}$ & Shallow water (<10 m) & Deep water (>15 m) & Widespread in FW \\
\hline & $\begin{array}{l}\text { Signals detected by antennas } \\
\text { (aerial or underwater) and a receiver } \\
\text { (some have logging capability) }\end{array}$ & $\begin{array}{l}\text { Low-conductivity } \\
(<500 \mu \mathrm{HS} / \mathrm{cm})\end{array}$ & $\begin{array}{l}\text { High } \\
\text { conductivitySensitive to } \\
\text { localized interference }\end{array}$ & $\begin{array}{l}\text { Fish and other taxa, especially } \\
\text { amphibious species (for } \\
\text { example, basking turtles, } \\
\text { amphibians, some mammals) }\end{array}$ \\
\hline
\end{tabular}

Tracking can occur from boat, vehicle, air, foot

Radio telemetry; As above

fixed stations

Fixed stations with multiple antennas detect and log tags when in the vicinity of an antenna

Most often deployed in riverine systems to detect migration

$\begin{array}{ll}\text { Passive } & \text { Integrated circuit chip and coil } \\ \text { integrated } & \text { antenna that transmits a unique } \\ \text { transponder } & \text { identity code when energized by a } \\ \text { telemetry; } & \text { low-frequency radio signal } \\ \text { manual tracking } & \text { (generally } 125 \text { to } 400 \mathrm{kHz} \text { ) }\end{array}$

Relatively inexpensive

Functions in moving water and through ice as well as on land and in air

As above

Suitable for long-term deployments

No battery (therefore long life)
Antennas visible, thus can Widespread use in FW attract vandals

Not possible to obtain precise two-dimensional positions (mostly presence or absence in a given location)

Sensitive to interference

Effectiveness dependent on local geomorphology and station placement [19]

Largely limited to shallow and restricted lotic systems owing to small detection range (usually < $1 \mathrm{~m}$ ) 


\section{Table 1 Summary of the various technologies used for tracking animals in freshwater with a brief summary of strengths, limitations, and common applications (Continued)}

\begin{tabular}{|c|c|c|}
\hline & $\begin{array}{l}\text { Detected using hand-held (usually } \\
\text { in a backpack with wand waved in } \\
\text { or above water surface while wading or } \\
\text { walking on ice) or boat-mounted readers }\end{array}$ & Small \\
\hline & & Inexpensive \\
\hline \multirow{3}{*}{$\begin{array}{l}\text { Passive } \\
\text { integrated } \\
\text { transponder } \\
\text { telemetry; fixed } \\
\text { stations }\end{array}$} & As above & $\begin{array}{l}\text { No battery (therefore } \\
\text { long life) }\end{array}$ \\
\hline & $\begin{array}{l}\text { Antennas deployed in systems that } \\
\text { record the time and unique ID of a } \\
\text { given tag detection }\end{array}$ & Small \\
\hline & $\begin{array}{l}\text { A variety of antenna designs, mostly for } \\
\text { small lotic systems, fishways or other } \\
\text { areas where animals congregate }\end{array}$ & Inexpensive \\
\hline \multirow{2}{*}{$\begin{array}{l}\text { Low-frequency } \\
\text { electromagnetic } \\
\text { telemetry }\end{array}$} & $\begin{array}{l}\text { Similar principle as PIT tags, but tags are } \\
\text { continually powered }\end{array}$ & \multirow{2}{*}{$\begin{array}{l}\text { Effective in areas with } \\
\text { high noise levels where } \\
\text { acoustic and radio may } \\
\text { be problematic }\end{array}$} \\
\hline & $\begin{array}{l}\text { Greater detection range on the order of } \\
\text { several tens of metres (for example, } \\
{[20,21] \text { ) }}\end{array}$ & \\
\hline \multirow[t]{2}{*}{$\begin{array}{l}\text { Combined } \\
\text { acoustic radio } \\
\text { transmitters }\end{array}$} & $\begin{array}{l}\text { Both acoustic and radio output modules } \\
\text { can either transmit simultaneously or, if } \\
\text { dynamic, can switch between the two }\end{array}$ & Works in marine and FW \\
\hline & $\begin{array}{l}\text { Switching driven by environmental cues } \\
\text { (depth or conductivity) [22] }\end{array}$ & $\begin{array}{l}\text { Works for animals that } \\
\text { use a wide range of } \\
\text { depths or move into } \\
\text { higher conductivity } \\
\text { waters }\end{array}$ \\
\hline $\begin{array}{l}\text { Archival tags (no } \\
\text { transmitting } \\
\text { capability) }\end{array}$ & $\begin{array}{l}\text { Biologging tags (for example, data } \\
\text { storage tags, time-depth recorders, } \\
\text { archival geolocation tags) }\end{array}$ & $\begin{array}{l}\text { Continuous monitoring } \\
\text { of desired parameter (for } \\
\text { example, temperature, } \\
\text { depth) }\end{array}$ \\
\hline
\end{tabular}

Do not transmit data remotely

Always equipped with some form of sensor

Communicating Hybrid loggers and transmitters, first histogram acoustic transponders and business card tags

Smart positiononly tag with real-time GPS depth)

Useful for wide-ranging fishes that have low recapture probabilities but return to download sites [23] logging data to memory and later transmitting data when interrogated by a receiver

Business card tags are a variant where the logging function actually serves as a mini acoustic receiver and can log other tagged animals that it encounters [24]

Satellite platform transmitter which identifies tag location by real-time uplinks to orbiting Argos satellites whenever tag breaches the water surface (some variants may include archival capability rather than only transmitting in real time)

Multiple tags in the same Mostly in small fishes, reptiles, location can prevent amphibians and invertebrates signal transmission

Detection range depends on tag orientation relative to the reader

As above

Widespread use in FW

Remote stations require power source to function

Mostly for fish

Real-time positioning

Provides information on broad-scale movement of animals (for example, ocean basin scale)
Site-specific detection only

Limited tag life

Large devices

More expensive than either radio or acoustic tags

Require tag recovery to download data from onboard memory

Reasonably large

Limited use in FW

The few examples use fish in lowland rivers [20]

Some use in large diadromous fish species and marine mammals that move between marine and fresh waters

Some use in FW, mostly for logging temperature, depth, geolocation, and other environmental parameters (especially for ectothermic animals)

Occasionally log physiological information (for example, acceleration, heart rate)

Not applied in FW to our knowledge (mostly marine applications)

Expensive

Some versions require that tags are retrieved to download data

Relatively expensive
Individual must breach
water

Mostly marine

Some use in large FW animals that surface (for example, alligators, manatees) 


\section{Table 1 Summary of the various technologies used for tracking animals in freshwater with a brief summary of strengths, limitations, and common applications (Continued)}

\begin{tabular}{|c|c|c|c|c|}
\hline & & $\begin{array}{l}\text { Detailed records of } \\
\text { environmental } \\
\text { conditions experienced }\end{array}$ & & \\
\hline \multirow[t]{4}{*}{$\begin{array}{l}\text { Archival pop-up } \\
\text { satellite archival } \\
\text { transmitter tags }\end{array}$} & $\begin{array}{l}\text { Tags programmed to jettison at a given } \\
\text { time or when tags experience a specific } \\
\text { event (for example, fail to change depth } \\
\text { for a specified period of time) at which } \\
\text { time they float to surface and transmit } \\
\text { summary data or packets to satellites }\end{array}$ & $\begin{array}{l}\text { Provides information on } \\
\text { broad-scale movement } \\
\text { of animals (for example, } \\
\text { ocean basin scale) }\end{array}$ & $\begin{array}{l}\text { Most release links based } \\
\text { on corrosive link, } \\
\text { switched on via applied } \\
\text { voltage and require sea- } \\
\text { water to function }\end{array}$ & Mostly marine \\
\hline & $\begin{array}{l}\text { Geopositioning commonly based on } \\
\text { light levels }\end{array}$ & $\begin{array}{l}\text { Detailed records of } \\
\text { environmental } \\
\text { conditions experienced }\end{array}$ & Limited to large animals & $\begin{array}{l}\text { Most FW applications involve } \\
\text { diadromous animals tagged } \\
\text { during FW phase with pop-off } \\
\text { scheduled for when they are in } \\
\text { marine systems }\end{array}$ \\
\hline & Can also log depth and temperature & & Relatively expensive & $\begin{array}{l}\text { Exception: studies on FW } \\
\text { porpoises [25] }\end{array}$ \\
\hline & & & $\begin{array}{l}\text { Tags and downloading } \\
\text { technology not always } \\
\text { reliable, needs further } \\
\text { refinement }\end{array}$ & \\
\hline
\end{tabular}

FW, freshwater; GPS; global positioning system; VHF, very high frequency.

tags as small as $10 \mathrm{mg}$ are commercially available at the time of publication.

\section{Coded signals}

The advent of coded transmitter signals is a technical advance that made a major impact on the study of freshwater animals. Prior to the mid-1980s, most telemetry studies were limited to small numbers of individuals (usually <40) in relatively confined areas. The need for more quantitative data on large aggregates of fish, such as the timing and number of returning adult salmon and their migration through entire watersheds [67], made it necessary to develop new approaches for dealing with large numbers of wide-ranging individuals. Because of the commercial importance of Pacific salmon returns in north-western North America, funding was often available to support these developments, which subsequently had transferable benefits for studying other species. In addition to increasing the number of frequencies being monitored, transmitters encoded with simple, audibly distinguishable signal patterns (for example, single, double and triple-pulsed transmissions) or varying pulse rates (for example, 60 vs. 90 pulses per minute) were used to increase the number of unique individuals that could be identified. By the late 1980s, more sophisticated signal patterns were adopted, which together with receivers able to distinguish the encoded signal, dramatically increased the number of individuals that could be identified [42]. For acoustic applications, the advent and application of code division multiple access technology enabled multiple animals to be detected simultaneously [51]. Coded tags are now taken for granted, but represented a significant innovation for freshwater systems.

\section{Stationary tracking}

Passive telemetry systems (where receivers are deployed at stationary locations to record tagged animals that come within range of an antenna or hydrophone) in freshwater were based on coded transmitter technology. Receivers deployed throughout watersheds, and linked via satellite to relay data back to a central processing facility, were first deployed for Pacific salmon to study their upstream spawning migration [67]. Receivers could be programmed to scan a variety of frequencies and antennas, either sequentially or simultaneously (for example, using digital spectrum processing [68,69]), sometimes in an intelligent manner such that when fish were present they would prioritize 'listening' on a given antenna or frequency [19]. Stationary acoustic receiver systems were first used in marine systems [70,71] and are now routinely applied in inland waters, especially large rivers, lakes and reservoirs to assess migration patterns [72]. Hydrophones, coding and signal-processing advances mean that freshwater animals can now be tracked in river systems that were too turbulent and noisy for previous acoustic systems [71,73-75]. Autonomous omnidirectional acoustic receiver-loggers can be deployed in arrays to efficiently record diadromous fishes migrating between freshwater and marine systems, by enabling the same individuals to be employed in both habitats. This is even possible for small fish, thanks to the availability of relatively small transmitters compared with the combined acoustic and radio tags (CARTs) previously available). This technology, when used in combination with archival tags, has enabled researchers to describe detailed behaviour of steelhead trout during the riverine and oceanic migration [76]. Many of the passive 


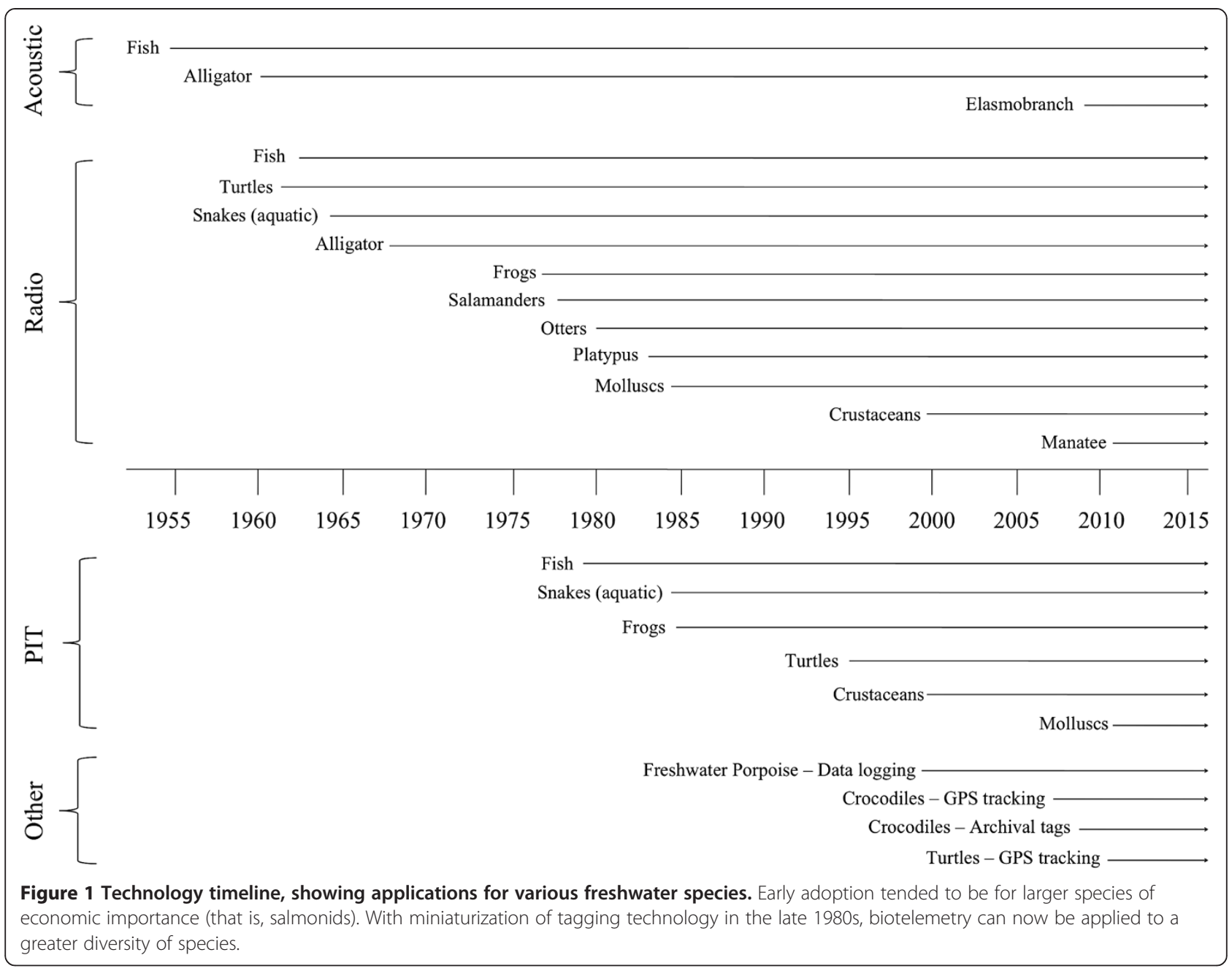

acoustic systems can be deployed subsurface and operate autonomously for extended periods (over a year) without requiring additional maintenance and battery changes, which has allowed for continuous tracking of the behaviour of freshwater species [23,38]. Recent developments include links to communication systems (for example, satellites, cellular networks, underwater acoustic modems) to enable data collection without retrieval of equipment. Large-scale acoustic telemetry arrays have now been installed in the Laurentian Great Lakes and many large river systems around the globe, and are based on international collaborations in transboundary waters focussing on wide-ranging animals. If configured with a minimum of three time-synchronized hydrophones, hyperbolic navigation using time difference in signal arrival can be used to generate highly accurate and precise animal positions [42,70]. To date, there are only a few published examples using such technology in freshwater, which have focused on questions of spatial distribution and variation in temporal activity $[26,27,77]$, but many projects using that approach are now under- way, including some that use relatively inexpensive technology to look at simultaneous fine-scale movements of multiple individuals [78]. Passive PIT telemetry arrays (discussed below) have also provided similar benefits. Development in antenna technology robust to dynamic river and stream conditions [32] has enabled longerterm field deployments.

The technical contributions noted above have led to a number of important and unique ecological advances. Unlike many marine and terrestrial ecosystems, rivers are by nature linear. The work of Fausch et al. [32] was instrumental in discussing some of the problems associated with trying to conduct ecological research broadly within the 'riverscape'. Telemetry applications provide a rare exception; a research method that actually capitalizes on the physical structure of dendritic freshwater ecosystems in capturing movement processes. For this reason, stationary receiver-loggers (often termed automatic listening stations) of radio, acoustic and inductive coupling forms have been deployed along many reaches of rivers to determine rates of movement and survival 
Table 2 Summary of key constraints (categorized by abiotic, anthropogenic, environmental/habitat, and biotic) associated with using electronic tags to study animals in freshwater systems, existing technical solutions, and additional technical needs that need to be addressed to improve equipment performance and science outcomes

\begin{tabular}{lll}
\hline Category & Condition & Constraint \\
\hline Abiotic & Ice cover in & In some regions ice cover for part of \\
& lentic & the year impedes access the water \\
& systems &
\end{tabular}

Modifies signal properties (for example, via reflections, noise)

May create problems during breakup by moving or damaging equipment

Abiotic Ice dynamics in lotic systems (especially acoustic telemetry [31])

Abiotic Shallow water

Abiotic

Thermocline

Abiotic

High flows, currents and turbulence
Winter ice dynamics pose problems for gear deployed in water due to potential damage (for example, PIT antennas, hydrophones [28])

Loss of reception associated with noise and physical obstruction

Exceptionally shallow water (for example, 0 to $30 \mathrm{~cm}$ or even ephemeral systems, like billabongs) can expose underwater hydrophones and make manual acoustic tracking nearly impossible [34]

Deep water attenuates radio signals $[35,36]$ and makes use of radio transmitters and PIT tags ineffective for positioning (in the latter case by virtue of the current difficulty of deploying PIT antennae at depth, though technically feasible if linked in situ with waterproofed logger and power supply)

Thermoclines can impair the performance of acoustic transmitters $[38,39]$, but radio transmitters are unaffected (aside from the fact that thermoclines often occur at depth)

Radio telemetry is favoured for tracking [29,30]

Flatbed PIT antennas reasonably robust to ice processes [32]

In small streams, use mobile PIT antennas through the ice [33]

Radio telemetry and mobile PIT antennas can be used in shallow water

Care must be taken not to disturb or chase animals being tracked

Acoustic telemetry performs well in deep water but positioning accuracy will depend on depth

Can use CART tags [22]

A downrigger device has been developed that enables tracking of limited reception zone [37]

Low-frequency radio tags can improve performance in deep water [35] as can use of more powerful batteries or stronger transmitter output [36] above and below thermoclines to improve reception, or at the same level as the fish being tracked if they do not frequently cross the thermocline

Rarely is performance so degraded that acoustic detections are not possible, but may impede ability to

High water flows in riverine systems or from lentic currents (creating noise on hydrophones) and associated turbulence and entrained air (even in low flows) can impede the performance of acoustic telemetry systems [40]

Increasing the density of acoustic receivers can improve detection probability [40] radio-tagged fish at depth, but has

Existing technical solutions

When ice conditions are safe animals can be tracked through the ice with radio receivers on foot (skiing, snowshoeing) or driving (for example, snowmobile)

Acoustic receivers can be deployed below ice but must be moored so that they are not dragged during ice breakup (for example, do not use surface buoys [26])

Hydrophones can be placed both achieve fine-scale positioning

Additional technical needs

Little information on acoustic performance under ice but some evidence of noise from cracking or shifting reducing detections (Mike Parsley, personal communication)

Understand the performance of acoustic telemetry (especially for logging and automated positioning) under the ice [27]

For PIT and acoustic systems there is need for antenna and receiver designs that are not subject to ice damage

Limitations due to physics and physical constraints unlikely to be overcome with technology

Unlikely that technical developments will improve performance of radio and PIT systems in deep water

Unlikely that technical developments will entirely address this issue with acoustic tags
There is need for technical developments further refining code detection and noise filtering in acoustic telemetry systems deployed in high flows, currents and turbulence 
Table 2 Summary of key constraints (categorized by abiotic, anthropogenic, environmental/habitat, and biotic) associated with using electronic tags to study animals in freshwater systems, existing technical solutions, and additional technical needs that need to be addressed to improve equipment performance and science outcomes (Continued)

\begin{tabular}{|c|c|c|c|c|}
\hline & & & $\begin{array}{l}\text { Fixed acoustic receiver station } \\
\text { deployment innovations enable their } \\
\text { placement in large rivers [41] }\end{array}$ & $\begin{array}{l}\text { Shielding of hydrophones may help } \\
\text { to reduce noise (Dale Webber, } \\
\text { unpublished data) }\end{array}$ \\
\hline & & & $\begin{array}{l}\text { Radio telemetry is unimpeded by } \\
\text { such conditions }\end{array}$ & \\
\hline & & & $\begin{array}{l}\text { Fixed PIT systems may be difficult to } \\
\text { maintain in high flows (get washed } \\
\text { out) }\end{array}$ & \\
\hline \multirow[t]{2}{*}{ Abiotic } & \multirow[t]{2}{*}{ Turbidity } & $\begin{array}{l}\text { High turbidity (especially if associated } \\
\text { with suspended matter) can impair } \\
\text { performance of acoustic systems [42] }\end{array}$ & $\begin{array}{l}\text { Acoustic systems usually perform } \\
\text { well except in extreme turbidity }\end{array}$ & \multirow{2}{*}{$\begin{array}{l}\text { Need to develop alternative ways of } \\
\text { positioning animals with sensors that } \\
\text { do not require light levels (that is, } \\
\text { PSATs) }\end{array}$} \\
\hline & & $\begin{array}{l}\text { Makes use of light sensors to position } \\
\text { animals ineffective (for example, } \\
\text { loggers or PSATs) }\end{array}$ & Radio and PIT are much less affected & \\
\hline \multirow[t]{4}{*}{ Abiotic } & \multirow[t]{4}{*}{ Conductivity } & \multirow[t]{4}{*}{$\begin{array}{l}\text { High conductivity can severely } \\
\text { attenuate VHF and HF radio signals in } \\
\text { particular but can also reduce } \\
\text { performance of acoustic telemetry } \\
\text { systems [34] }\end{array}$} & $\begin{array}{l}\text { The extent of radio signal attenuation } \\
\text { varies by radio frequency such that } \\
\text { choice of lower frequencies (for } \\
\text { example, } 30 \mathrm{MHz} \text { ) can improve } \\
\text { performance }[43,44]\end{array}$ & \multirow[t]{4}{*}{$\begin{array}{l}\text { Innovations in the marine realm for } \\
\text { devices that function well in high } \\
\text { salinity (and thus high conductivity) } \\
\text { potentially benefit freshwater } \\
\text { research }\end{array}$} \\
\hline & & & $\begin{array}{l}\text { Conductivity presumably also } \\
\text { influences PIT system performance } \\
{[45]}\end{array}$ & \\
\hline & & & $\begin{array}{l}\text { Compared with radio, acoustic } \\
\text { performance is relatively unaffected } \\
\text { by high conductivity }[33,46]\end{array}$ & \\
\hline & & & Can use CARTs [22] & \\
\hline \multirow[t]{3}{*}{ Abiotic } & \multirow[t]{3}{*}{ Salinity } & $\begin{array}{l}\text { Saline environments have very high } \\
\text { conductivity and make VHF and HF } \\
\text { telemetry unusable (as above) }\end{array}$ & $\begin{array}{l}\text { In saline environments, PSATs based } \\
\text { on corrosive releases that enable tags } \\
\text { to be jettisoned can be used }\end{array}$ & \multirow[t]{3}{*}{$\begin{array}{l}\text { Development of PSAT releases that } \\
\text { work in freshwater would provide } \\
\text { new tracking opportunities }\end{array}$} \\
\hline & & $\begin{array}{l}\text { High salinity has an effect on how } \\
\text { much sound energy water absorbs } \\
\text { [47], which is relevant for acoustic } \\
\text { tracking }\end{array}$ & $\begin{array}{l}\text { Corrosive releases do not work in } \\
\text { low-salinity environments; limits use } \\
\text { of PSATs in inland systems }\end{array}$ & \\
\hline & & & $\begin{array}{l}\text { Most inland systems would not have } \\
\text { problems with radio attenuation or } \\
\text { acoustic energy absorption due to } \\
\text { salinity }\end{array}$ & \\
\hline \multirow[t]{3}{*}{ Abiotic } & \multirow[t]{3}{*}{$\begin{array}{l}\text { Air-water } \\
\text { interface }\end{array}$} & \multirow{3}{*}{$\begin{array}{l}\text { Some animals move in and out of } \\
\text { water frequently (for example, turtles) } \\
\text { despite being primarily aquatic, } \\
\text { which leads to varied signal strength } \\
\text { for radio tags and no signal for } \\
\text { acoustic tags when in the air }\end{array}$} & $\begin{array}{l}\text { Most studies of animals at the } \\
\text { interface use radio telemetry } \\
\text { although satellite and GPS tags can } \\
\text { also be effective }\end{array}$ & \multirow[t]{3}{*}{$\begin{array}{l}\text { Unlikely that technical solutions will } \\
\text { address these issues }\end{array}$} \\
\hline & & & $\begin{array}{l}\text { Acoustic tags can still be used to } \\
\text { quantify timing and duration of out } \\
\text { of water activities (for example, } \\
\text { basking in turtles) }\end{array}$ & \\
\hline & & & CART technologies can be used & \\
\hline \multirow[t]{2}{*}{ Anthropogenic } & \multirow[t]{2}{*}{$\begin{array}{l}\text { Human } \\
\text { activity and } \\
\text { vandalism }\end{array}$} & $\begin{array}{l}\text { In areas with human activity, some } \\
\text { telemetry infrastructure is } \\
\text { conspicuous and can attract vandals } \\
{[48]}\end{array}$ & $\begin{array}{l}\text { Acoustic receivers, if deployed at } \\
\text { depths and using gear that the } \\
\text { public cannot easily reach, are usually } \\
\text { safe from vandals }\end{array}$ & \multirow{2}{*}{$\begin{array}{l}\text { Development of less conspicuous } \\
\text { deployments for radio and PIT gear, } \\
\text { such as autonomous underwater } \\
\text { antennas and receiving systems (as is } \\
\text { common in acoustic telemetry) }\end{array}$} \\
\hline & & $\begin{array}{l}\text { Swim-through PIT loops, with the top } \\
\text { edge above the water surface should } \\
\text { not be deployed where boats occur }\end{array}$ & $\begin{array}{l}\text { Most fixed-radio and PIT tag antenna } \\
\text { arrays (unless in controlled access } \\
\text { areas) are subject to vandalism even } \\
\text { when using 'vandal-resistant' gear }\end{array}$ & \\
\hline
\end{tabular}


Table 2 Summary of key constraints (categorized by abiotic, anthropogenic, environmental/habitat, and biotic) associated with using electronic tags to study animals in freshwater systems, existing technical solutions, and additional technical needs that need to be addressed to improve equipment performance and science outcomes (Continued)

\begin{tabular}{|c|c|c|}
\hline \multirow[t]{2}{*}{ Anthropogenic } & $\begin{array}{l}\text { Human } \\
\text { infrastructure } \\
\text { and } \\
\text { construction } \\
\text { materials }\end{array}$ & $\begin{array}{l}\text { Human infrastructure (for example, } \\
\text { fishways, dams) are often studied } \\
\text { using electronic tags but the } \\
\text { construction materials (for example, } \\
\text { concrete, metal), operations (for } \\
\text { example, entrained air, high flows), } \\
\text { and electromagnetic activity (for } \\
\text { example, from hydro wires) can } \\
\text { interfere with radio, PIT and acoustic } \\
\text { systems }\end{array}$ \\
\hline & & $\begin{array}{l}\text { Background radio noise over a wide } \\
\text { range of frequencies (for example, } \\
\text { communication systems and } \\
\text { electrical devices) }\end{array}$ \\
\hline
\end{tabular}

Anthropogenic Noise

Environment or habitat noise can all make detection of acoustic signals difficult the water column [47] (for example, fixed and locked boxes [48])

Miniaturization of power systems and autonomous receivers has helped to deploy receivers out of sight

Labeling the equipment with information on content, purpose and value of equipment may reduce likelihood of vandalism in some areas

Underwater radio antennas can be used in areas near electrical infrastructure to reduce interference [49]

Continued development of equipment that is robust and shielded from electromagnetic activity

Many efforts have been devoted to developing acoustic systems that can work around infrastructure

PIT arrays work well in such areas but need to be cautious around metal surfaces

Use existing coding systems to avoid background interference

Prior to starting a study, identify frequencies that are prone to high levels of interference in your area

Boat traffic, waves, rain and biological Radio and PIT unaffected unless electrical interference from vessels (including electromagnetic noise interference from tracking boat [22)

For example, rainfall can produce or Much less biological noise in increase noise levels of 15 to $25 \mathrm{~dB}$ in freshwater than marine systems, so not a problem in most situations

Solar panels and special battery banks have provided power in remote locations for fixed stations (mostly radio and PIT systems [50])

Satellite connections enable data to be retrieved and receivers to be configured from afar (already exists for radio [51] and recently developed for acoustic systems with a surface cable and GPS or cell interface)

Aircraft-mounted antennas can be used for radio tracking animals over great distances in remote locales $[52,53]$
Improvements in coding to improve performance when signal to noise ratio is not optimal for acoustic systems

Conducting detailed systemperformance tests under different conditions needed to determine acoustic system efficiency (for example, in a shipping canal)

Need for technological improvements to address challenges with maintaining systems in winter or damp environments (for example, better weatherproofing of equipment [48])

More remote communication options to enable servicing from afar

Batteries that last longer or systems that require less power 
Table 2 Summary of key constraints (categorized by abiotic, anthropogenic, environmental/habitat, and biotic) associated with using electronic tags to study animals in freshwater systems, existing technical solutions, and additional technical needs that need to be addressed to improve equipment performance and science outcomes (Continued)

\begin{tabular}{|c|c|c|}
\hline $\begin{array}{l}\text { Environment } \\
\text { or habitat }\end{array}$ & $\begin{array}{l}\text { Habitat } \\
\text { configuration }\end{array}$ & $\begin{array}{l}\text { Geomorphological configuration of } \\
\text { habitats (for example, type and } \\
\text { configuration of banks, fjords, } \\
\text { roughness of substrate, type of } \\
\text { substrate) can influence performance } \\
\text { of both acoustic }[40,54] \text { and radio } \\
\text { telemetry [55] }\end{array}$ \\
\hline
\end{tabular}

$\begin{array}{ll}\text { Environment } & \text { Cryptic } \\ \text { or Habitat } & \text { habitats }\end{array}$

$\begin{array}{ll}\text { Biotic Macrophytes } & \text { Macrophytes can impede sound } \\ & \text { when using acoustic telemetry [34] } \\ & \text { and can foul external telemetry } \\ & \text { transmitters [58] }\end{array}$

Biotic Animal damage

Biotic Biofouling acoustic arrays [59]) or damagesensitive electronics [48]

Algae and molluscs (for example,
Some animals make use of cryptic habitats that make tracking difficult (for example, crayfish and mammals can use burrows [57]; some fish hide under rocks [37]) due to signal attenuation and deflection; acoustic telemetry ineffective in such situations

Radio telemetry and PIT tracking possible if animals are not too deep into cover and can foul external telemetry transmitters [58] dense macrophytes mammals such as muskrats or insects such as ants) can chew through wires for cabled systems (including cabled Dreissena spp.) in particular can build up on underwater equipment, such as fixed hydrophones or underwater antennas, reducing performance [61]

Fouling of external tags can reduce performance and burden tagged animals [62]

Fouling of light sensors makes use of geopositioning tags in freshwate difficult cleaned (for example, by divers) or
Increasing density of acoustic receivers can improve detection probability in some areas (for example, such as near banks in rivers or areas with high levels of substrate roughness [56])

Manual radio tracking can be confusing around some habitats (for example, rock walls) such that practice is needed to become efficient at locating tags

Use tags that are as powerful as possible (for example, high-output radio tags)

Unclear if specific frequencies or other characteristics of acoustic telemetry systems would improve performance in dense macrophyte beds

Radio telemetry performs well in

Use internal tag implantation in animals that are in regions with lots of macrophytes

Wires can be protected with sheaths and various pest control strategies

can be used (for example, pesticides in land-based fixed stations)

External tags can be designed to minimize chewing by mammals (for example, was a problem for box turtles [60])

Underwater equipment such as

Need for additional studies to better understand how habitat configuration influences detection of radio and acoustic telemetry signals

An intrinsic challenge that cannot be easily overcome with technology

Efforts should focus on training of team members to track in such environments

Need for rigorous testing of acoustic telemetry gear in and around macrophytes to identify ideal frequencies for local conditions

Further developments such that cabled systems are not needed

Development of strategies for camouflaging and protecting wires and making gear sealed to prevent entry of insects

Need for biofouling paints and materials that are minimally toxic various biofouling materials (for example, special paints [61]) can be used

Tags (and antennas) can be placed internally [62] animals without light
Need for methods of geopositioning 
$[20,22,75,79,80]$ and along diverging paths to the sea to determine route selection [20,81]. While the use of acoustic telemetry arrays in marine environments has provided important spatial data for large-bodied marine fauna, there has been an even greater rate of return for investment in telemetry infrastructure in rivers. This is largely a function of the contained and branching nature of rivers, when compared with the unconstrained shape of most marine areas in relation to the relatively limited range of acoustic receivers.

\section{PIT telemetry}

Passive integrated transponder telemetry has provided an affordable tool that enables researchers to study smaller individuals or juvenile life stages than is possible with radio and acoustic telemetry using both active and passive tracking. In addition, tags remain viable for long periods (years), owing to the lack of onboard batteries, allowing long-term tracking of individual fitness proxies, such as growth and survival [16,82-84]. Owing to the much shorter range (less than $2 \mathrm{~m}$ perpendicular to the antenna plane) than radio and acoustic transmitters, PIT telemetry has mainly been used in smaller systems. It is especially valuable in assessing fish movement through narrow passageways, such as fish passes [85] and streams $[86,87]$, but is increasingly used in wider swimthrough channels $(30+\mathrm{m} \times 0.8 \mathrm{~m}$ deep) using an array of tag readers. Passive systems yield high-quality longterm recording of large samples of animals at discrete locations [88]. Mobile PIT detectors (backpack and boat or trawl-mounted models for example [89]) have been developed as a less obtrusive method for studying the ecology of refuge-seeking or cryptic species of fish, invertebrates (for example crustaceans [90,91], molluscs) and amphibians [92]. One prominent innovation with PIT telemetry has been the ability to visit bird colonies to estimate predation on small fish (mostly salmonid smolts) by locating PIT tags on land [93]. Further, the cost of PIT tags remains about one hundredth of that of battery-powered radio and acoustic transmitters, facilitating large sample sizes with PIT telemetry.

\section{Sensor tags}

The incorporation of sensors into radio and acoustic transmitters and archival tags has provided novel insight into animal-environment associations and the energetic costs of different behaviours (for example, basking) and stressors (for example, fisheries interactions, fishway use). Some of the earliest sensors incorporated into electronic tags were simple activity or motion sensors that provided the status of a fish (that is, whether it is moving or stationary [94]). The success of these tags encouraged the development of other sensor types. Physiologically oriented sensors (for example, electrocardiography; electromyo- graphy, acceleration) have been used primarily on fish $[95,96]$. Electromyography sensors incorporated in radio transmitters were developed in the 1970s to record opercular muscle activity or overall fish locomotor activity [97-99], and are today the most commonly used physiological sensor tool for studying energetics and migration in freshwater fish [17]. Electrocardiography or other cardiac metrics, such as heart rate (see [100] for review) have been used in radio (for alligators [101] and for fish [102]), acoustic (for fish [103]) and archival (for fish [104,105]) tags. Of late, acceleration loggers $[105,106]$ and acoustic acceleration transmitters (SJC, unpublished data) have been used to assess temporal changes in energy expenditure and movement rate and are expected to grow in popularity for application in freshwater, akin to the uptake of this technology in terrestrial and marine applications $[107,108]$. Environmental sensors, particularly temperature and pressure (that is, depth [109]), have been used on a wide range of reptiles (for example, turtles [110]) and fish [111] and have been used in radio and acoustic transmitters and archival tags to link location with the environmental parameters measured by the sensors. Other environmental sensors linked to transmitters have also been designed to assess the range of key parameters, such as conductivity [112] and oxygen [113], that fish are exposed to during normal activity. Relatively cheap archival temperature tags now available on the market enable collection of long-term thermal information and large sample sizes, provided that the tags can be retrieved (for example, alligators [114], turtles [115], salmon [116]). Early sensor tags were developed by individual researchers, who would build the tags either themselves or in collaboration with engineers [112,117-119]. However, many of these sensors now represent 'standard' options for commercially available tags, and their use is greatly simplified. Collectively, these tools have provided novel insights in animal behaviour, energetics and physiology that would not be possible by simply measuring the location of an animal.

\section{Integration of peripheral technologies}

In addition to improvements specific to telemetry and logging equipment, advances in other, often unrelated, technologies have dramatically increased the options available to researchers and made them easier to adopt. For example, availability of low-cost GPS, some even integrated with receiving systems, has improved the positional accuracy and usability of the telemetry data collected (a vast improvement over drawing circles on a map [52]) allowing fine-scale assessment of movement. Uplink technology (for example, satellite, Wi-Fi, cellular, Bluetooth) and nonvolatile data storage has made it faster and easier to recover telemetry data from stationary tracking systems, particularly those in remote or inaccessible areas. Computerized databases have increased 
the efficiency of data analyses, and links to the internet make the information easier to disseminate and widely available.

\section{Tagging techniques}

More so than in marine environments, significant effort has been devoted to the development and validation of various attachment and implantation procedures (including pre- and post-tagging care), particularly for fish (reviewed in $[58,120,121]$ ) but also for reptiles [122]. If the tags or associated tagging procedures result in altered behaviour, energetics, condition or survival relative to untagged conspecifics, then findings emanating from tagging studies may be biased or incorrect [28]. Most research efforts have focused on identifying the maximum tag burdens for a range of taxa (including turtles, fish and amphibians), testing and optimizing tagging techniques, assessing different tag types, [123,124], testing anaesthetics (for example, for turtles [125] and fish [126]), and identifying species- or taxon-specific challenges [120]. These challenges often relate to the composition, rigidity or permanence of an animal's outer surface in regard to externally tagging (for example, reptiles [122,127], an elasmobranch [128], a slippery fish [129], crayfish [91]) or physiological acceptance of foreign bodies following internal tagging $[130,131]$. Particularly in freshwater, fouling of external tags (for example, with macrophytes) and associated impacts on drag have led to innovations in internal surgical procedures [132] that have advanced tagging for marine fish. Indeed, many of the refinements in animal handling associated with the development of tagging procedures for freshwater fish have led to broader improvements in and attention to animal welfare for aquatic animals used in research [133].

\section{Combining electronic tagging with other research methods}

Although early studies focused largely on using electronic tags to identify habitat use and movements (that is, descriptive; reviewed in [15]), electronic tagging is increasingly being combined with other techniques and tools. Such advances have increased the complexity of questions that can be addressed and provide more mechanistic explanations of animal behaviour through hypothesis testing (reviewed in [134]). This can be accomplished with integrative studies that combine techniques in parallel (for example, a study that has a laboratory and field component), by obtaining nonlethal biological samples from tagged animals (for example, stable isotope analysis [135], genetic tests [136], physiological status studies $[27,137])$, or by experimentally manipulating tagged animals (for example, hormone manipulations [138], controlling feeding [139], cortisol injections [59]) or their environment (for example, temporary holding studies followed by release [140]).
Some of the earliest of such studies occurred on Pacific salmon in Japan and involved evaluating homing mechanisms [141] and the endocrinology of migration (reviewed in [142]). Recently, the first example of combining genomic studies with field telemetry of Pacific salmon identified the factors that are associated with migration failure in freshwater [143]. Integration of fish telemetry with detailed hydrodynamic studies has been used to optimize fish passage facilities through improved understanding of fish cognition and behaviour [144]. The number of such integrative studies appears to be increasing.

\section{Data analysis tools and techniques}

Following their development for terrestrial applications, many of the analytical techniques now being applied in marine systems were first applied in freshwater [145]. Of particular note is the use of mark-recapture models (and software for fitting models) for estimating detection, survival and state transitions during migration through rivers [146,147]. These papers adapted Cormack-JollySeber and similar models (developed in the 1960s for survival through time) to salmon migration. More recently, survival analyses have been adapted for telemetry data from fishway assessments [148]. Voluminous amounts of data can be collected using telemetry but the advent of easy-to-use, computerized databases [149] has made it possible to organize and process data efficiently and present information in a highly useable form. Records of tag detections from many freshwater species have been entered into large databases managed by software such as ACCESS and HYDRA. The development of geographic information system (GIS) methods (for example, [150]), space-use analyses [151] and such computer programs as ARCVIEW, ARCINFO, RANGES and $\mathrm{R}$ has simplified and opened new possibilities for analyzing movement data in freshwater habitats. For example, fish telemetry data analyzed with home-range software led to important findings related to home-range establishment and shifts $[152,153]$. Nevertheless, most space-use analyses have been developed for terrestrial or marine applications and careful assessment of their applicability and bias is needed for the restricted and sometimes nearlinear habitats of freshwater systems [154].

\section{International collaborations}

Although not unique to this field, there has been a notable increase in the number of freshwater telemetry studies in remote areas around the world, and also in many less economically developed countries. These efforts have contributed significantly to solving basic and applied research questions in regionally important freshwater animals, and have broadened the habitat types and animal taxa covered by such studies. As noted previously, given the threatened status of freshwater ecosystems and their animal 
inhabitants, there is a great need for studies on fishes that support commercial and subsistence fisheries in less economically developed regions (for example, central Africa [62], the Mekong basin [155], the Amazon basin [48]). While biotelemetry has long been recognized as an important tool for freshwater research in these regions [156], its adoption has been driven by an apparent increase in available funding for international studies and collaborations, and for studies in developing countries, together with facilitation of such collaborations with the development of email communication and the internet, and greater affordability of equipment. Workshops have also been targeted towards building capacity for doing freshwater telemetry studies in less economically developed countries [157].

\section{Future needs}

The technical advances discussed in this paper have provided a strong foundation for the development of new technologies and technical innovations. Many of these advances will undoubtedly have an impact on the methods used to study aquatic animals and their surroundings. Although several emerging trends are evident in the literature (for example, advances in integrating and summarizing large data sets and the adaption of telemetry tools to novel species and environments), most can only be imagined. Here we provide an overview of what we regard as desirable future technical innovations and research needs related to the study of animals in freshwater systems (not ranked in any particular order). Most of these advances relate to transmitter design, tagging methods, tracking capabilities and tools for analyzing the large amounts of data collected. As in the past, many of the new technologies needed to overcome the constraints identified (Table 1) will probably come from advances in other fields that are then applied to fish and wildlife applications.

A major limitation with current telemetry systems is the size and functionality of the transmitters. Larger tags can provide increased reception range, operating life and sensor options, but limit the size of the individual and life stage that can be studied. Battery size is currently a limiting factor that dictates the ultimate size of the transmitter, the number and type of sensors that it can contain, and the duration of its longevity. Developing smaller, more efficient batteries to reduce transmitter size and increase operating life and reception range would help, but only to a limited degree. These technologies need to be combined with either hardware or software solutions that allow for more efficient power usage. Ultimately, more advanced tags will hopefully allow for near-lifetime tracking of large, long-lived animals from juvenile to adult in large freshwater systems (for example, large tropical catfishes).
While great strides have been made towards miniaturizing tags, there are limits to how far we can go with current technologies. In short, a technological wall has been reached that might significantly limit the extent to which we can study aquatic species. To that end, we preface this section by noting that in many ways we need a paradigm shift in the type of equipment we use to tag and track freshwater species. A component of this shift will be the development of tags that conserve battery power (to increase their lifespan and power peripheral sensors) until they are either required to collect data, or are transmitting data for collection. While not necessary for all applications, this transition will open up new avenues of research and innovation aimed at lifetime tracking of individual behaviour and environmental interactions. While the development of very small, long-lasting, inexpensive tags with a long range under a variety of environmental conditions remains an obvious but unlikely desire (dare to dream...), here we focus primarily on technical needs.

\section{Environmental conditions}

Given the extreme range of environmental conditions (for example, subarctic areas or tropical systems) that are home to freshwater species, adapting receiver technology for these conditions is essential. The production of field-ready (that is, waterproof, shock-proof) receiver housings would greatly expand the application of expensive telemetry equipment.

\section{Sensors}

While many sensors have been developed for a wide variety of applications, there are still areas where improvements to sensors or entirely new sensors would benefit the study of freshwater organisms. General improvements to both the reliability and ease of using complex sensors would make them more widely applicable. For example, while geolocation tags that use light or a magnetic field have produced valuable results, there is room to improve the algorithms used to derive their position. Reduced battery size has allowed for the development of PIT tags with simple sensors (for example, temperature). Further development of sensor and data storage PIT tags, as well as systems capable of transferring data from the tags, has great potential for large-scale studies. Work on this is ongoing in non-wildlife fields ([158]), but freshwater researchers should look to incorporate these technologies into their research.

While the concept has already been used in marine systems, freshwater animals may represent potentially useful bioprobes that can aid in environmental monitoring. A necessary component is the development of multisensor devices that provide spatial and environmental data that can be tracked over large spatial and 
temporal scales. At the individual level, mortality tags have been developed that broadcast when an individual stops moving for a set amount of time. As tag sizes have decreased, prey species have increasingly been the focus of telemetry studies. With motion-sensing mortality tags, prey that has been consumed by a predator may still appear to be alive; therefore, development of a tag that senses when an individual has been eaten would provide a more accurate indication of mortality.

The combination of real-time, simultaneous, hydroacoustic echo-sounding (horizontal or vertical) with interrogation of individuals with transmitters or transponders is a concept that dates back to Mitson and Storeton-West [159]. Given the numerous technological improvements since the 1970s, this approach should now be explored using state-of-the-art hydroacoustic equipment to simultaneously combine local-scale habitat and animal (especially fish) distribution and abundance to telemetered behaviour and ecophysiology of tagged individuals.

\section{Archival tags}

The major limitation associated with archival tags is the need to recapture tagged individuals to acquire stored data. A potential solution would be the development of archival tags with rapid download capability, probably downloaded as an individual moves through a remote gate. Since not all fish will pass near enough to such a structure, this design could be further improved through the addition of a 'chat' function that allows data to be exchanged between individuals and stored. This technology would be perfectly suited for species that are known to aggregate at some point in their lifecycle but may have low individual recapture rates (for example, adult sturgeon, which aggregate to spawn).

Although some large diadromous fish can be tagged with pop-up satellite archival transmitters (PSATs) in freshwater and pop-off transmitters in marine waters (for example, Atlantic sturgeon tagged in Hudson River [160]), there is a need for PSAT tags that function well in terms of both generating positions and 'popping-off' in freshwater. Presently, most pop-off assemblies are based on corrodible links that require a saline environment to degrade the attachment material, thereby limiting their application in freshwaters.

\section{Tag transmission}

Reception range, which should ideally be maximized due to the sizable areas typically associated with in-situ studies, is often marginal or inadequate. To expand the use of these studies to more complex environments, efforts should focus on improving monitoring systems that are capable of tracking animal movements in large, powerful river systems. Solutions will need to include overcoming underwater noise and improved deployment techniques for acoustic telemetry equipment. To combat background noise that interferes with detections (a common problem in urban areas or near infrastructure, such as power plants), unique radiotelemetry coding systems could be developed or site-specific frequencies could be selected. Similarly, novel coding-schemes may help to improve the effectiveness of acoustic telemetry when species are located among macrophytes.

Passive integrated transponder (PIT) tags have been used successfully to study a variety of aquatic species under controlled settings, but the reception range (typically less than a metre) is insufficient for many studies in large, unconstrained environments. The development of more robust and powerful PIT systems and antennas that work in larger environments and under a broader range of environmental conditions will extend the application of PIT tags. Possible solutions include the further development of PIT trawls and meshless static PIT 'gillnets' that detect tagged fish as they swim through them. In addition, when multiple PIT-tagged individuals pass through a stationary array, one tag may block the signal from another. The development of a method that prevents or circumvents this blockage is essential, to ensure that all individuals are detected.

For many telemetry studies, collecting large amounts of data is not a challenge. However, some variables (that is, continuous monitoring of depth or acceleration) are currently limited to archival storage tags. Advances in telemetric transfer and decoding of large or complicated datasets could expand the type of telemetry tags used for collecting continuous or long-term data. Similarly, enhanced telemetric transmission (in terms of rate and volume of data) would improve the transmission of video images (for example, 'critter cams') either in real time or using archival tags.

\section{Tagging techniques}

While a great deal of work has been directed towards improving tagging techniques (especially in fishes), further refinement of tagging procedures and validation of tagging techniques using the species being tagged (rather than surrogates [120]) are essential. This is particularly true for invertebrates, especially those that moult (for example, crustaceans). In addition to refining current techniques, there is also a niche for developing a rapid, internal tagging technique that can be used with aquatic vertebrates and large invertebrates (for example, development of injectable tags that are minimally invasive and require no anaesthetic).

\section{Arrays}

Two and three-dimensional arrays are one of the most promising new methods for tracking tagged individuals. Unfortunately, high costs and the complicated nature of 
both the system themselves and the data they produce limit their broad application. A cheaper and more user friendly two- and three-dimensional system would open new possibilities and improve studies of detailed individual movements in areas above and below dams and through fishways or other possible migration barriers. One of the major challenges associated with two- and three-dimensional arrays is the overwhelming amount of data that can be acquired. To encourage the application of these arrays, data filtering and spatial location calculation methods need to be developed that can be easily applied, ideally by the scientist rather than the vendor. While passive telemetry systems have been installed in small lakes and both large and small rivers, there is a need for the development of large-scale communal telemetry systems at the scale of watersheds and entire lakes [27]. This would allow for ecosystem telemetry studies and manipulations of individuals in their entire natural environment.

\section{Databases and analysis}

A broad theme for all of the aforementioned future developments is to improve user interfaces and make them more readily accessible to nonexperts. This concept of user-friendliness also holds true for computer programs designed to organize and analyze large and cumbersome databases. Software improvements that allow users to integrate and summarize large databases easily would be a great asset, and built-in functions, such as analysis of home range, would be useful (especially in spatially complex environments). Also, from a statistical perspective, models are needed that estimate spatial movement processes and survival probabilities while accounting for observation errors. State-space models seem to have some promise, but a general model framework and software are lacking.

\section{Collaboration}

An important part of realizing the seven future needs that we have identified is the fostering of a strong relationship between users of telemetry equipment and those that design and produce it. These relationships have been and will be central to technological advances in freshwater telemetry. Early on, there were relatively few commercial vendors so most researchers either built their own equipment or worked with technical staff within their own agency or institution. Indeed, many of the first commercial suppliers were former researchers themselves, and the spirit of cooperation continued as they developed their product lines and became established. Although the quality of telemetry gear has vastly improved in recent decades, the importance of collaboration between suppliers and users remains paramount. Most equipment purchases are based on predesigned items that may or may not be ideal. Many researchers assume that this is what is available and so make do, and vendors are often reluctant to make changes unless there is a clear upside for sales. Although this is understandable from an economic standpoint, it is not conducive to advancing the technology in a field where funding is often limited. Collaboration between field researchers and product designers and manufacturers is likely to be a key factor in relation to the utility and effectiveness of future advances.

\section{Conclusion}

Over the years, advances in electronic tags have had a significant impact on the ability to study aquatic animals under a variety of challenging conditions. Here, we reflected on the history of these advances and, in doing so, we were able to characterize the key technical developments that have made electronic tags such a useful tool in research. Most research activities and innovation have arisen from work on fish, but there is certainly an opportunity for greater application of such technology to other taxa and to smaller animals including invertebrates and amphibians.

Many constraints make the use of electronic tags challenging, but for most applications there is at least one form of technology that will work. The reality is that technological limitations require researchers to make trade-offs, which necessitates preparation of clear research questions and research priorities during the study design process. Different research questions may require the application of very different technologies. Compared to where the field was 50 years ago, we have come a long way. Innovations continue, as summarized here, but there are still a variety of future needs that, if achieved, could open more doors for studying freshwater animals. Electronic tag practitioners and equipment manufacturers need to work closely if such advances are to be meaningful and rapid. However, not all of those needs are purely technological, as continued work is needed on analytical and statistical procedures to handle the large volumes of data generated. Further, efforts to refine and validate tagging procedures to ensure that the data are representative of untagged conspecifics and that the welfare status of tagged animals is maintained, are still needed. Many meaningful gains in conservation and management will likely be ascribed to electronic tagging innovations in freshwater in the next 10 to 20 years, and we expect novel discoveries relating to fundamental animal and environmental biology. Indeed, with the growing threats facing freshwater ecosystems and their fauna, the need for further technical and technological improvements is urgent if the scientific community is to provide the data needed to inform conservation efforts. 


\section{Abbreviations}

CART: Combined acoustic radio transmitter; CDMA: Code division multiple access; CHAT: Communicating histogram acoustic transponder; GIS: Geographic information system; GPS: Global positioning system; HF: High frequency; PIT: Passive integrated transponder; PSAT: Pop-up satellite tag; SPOT: Smart position-only tag; USGS: United States Geological Survey; VHF: Very high frequency.

\section{Competing interests}

The authors declare that they have no competing interests.

\section{Authors' contributions}

All authors helped to identify important historical developments, current constraints and future needs for freshwater biotelemetry in their specific areas of expertise. In addition, JDM helped to synthesize these contributions and SJC wrote the initial draft of the manuscript. All authors were also involved in subsequent revisions of the manuscript. All authors read and approved the final manuscript.

\section{Acknowledgements}

SJC is supported by the Canada Research Chairs program and the Natura Sciences and Engineering Research Council of Canada (OTN Canada). We thank Greg Bulté for directing us towards relevant reptilian literature. The findings and conclusions in the paper are those of the authors and do not necessarily represent the views of the National Marine Fisheries Service). Reference to trade names or commercial products does not imply endorsement or recommendation by the National Marine Fisheries Service, NOAA, the USGS or the US Government. This manuscript is contribution number 1745 of the USGS Great Lakes Science Center.

\section{Author details}

${ }^{1}$ Fish Ecology and Conservation Physiology Laboratory, Department of Biology, Carleton University, 1125 Colonel By Dr., Ottawa, ON, Canada. ${ }^{2}$ Biotelemetry Laboratory, Department of Fish, Wildlife and Conservation Biology, University of California at Davis, Davis, CA, USA. ${ }^{3}$ Aquatic Animal Ecology Research Group, School of Biological and Biomedical Sciences, Durham University, Durham, UK. ${ }^{4}$ Norwegian Institute for Nature Research, Trondheim, Norway. ${ }^{5}$ Auke Bay Laboratories, Alaska Fisheries Science Center National Marine Fisheries Service, National Ocean and Atmospheric Administration, Juneau, AK, USA. ${ }^{6}$ Hammond Bay Biological Station, United States Geological Survey, Millersburg, MI, USA. ${ }^{7}$ Tropical Landscapes Joint Venture, CSIRO Ecosystem Sciences \& TropWATER, James Cook University, Atherton, QLD, Australia.

Received: 1 November 2012 Accepted: 5 March 2013

Published: 1 May 2013

\section{References}

1. Brinson MM, Malvárez Al: Temperate freshwater wetlands: types, status and threats. Environ Conserv 2002, 29:115-133.

2. Brönmark C, Hansson LA: Environmental issues in lakes and ponds: current state and perspectives. Environ Conserv 2002, 29:290-306.

3. Malmqvist B, Rundle $S$ : Threats to the running water ecosystems of the world. Environ Conserv 2002, 29:134-153.

4. Vörösmarty CJ, McIntyre PB, Gessner MO, Dudgeon D, Prusevich A, Green P, Glidden S: Global threats to human water security and river biodiversity. Nature 2010, 467:555-561.

5. Moyle PB, Leidy RA: Loss of biodiversity in aquatic ecosystems: evidence from fish faunas. In Conservation Biology: The Theory and Practice of Nature Conservation, Preservation, and Management. Edited by Fiedler PL, Jain SK. New York: Chapman and Hall; 1992:127-169.

6. Dudgeon D, Arthington AH, Gessner MO, Kawabata ZI, Knowler DJ, Leveque C, Naiman RJ, Prieur-Richard AH, Soto D, Stiassny MLJ, Sullivan CA: Freshwater biodiversity: importance, threats, status and conservation challenges. Biol Rev 2006, 81:163-182.

7. Ormerod SJ, Dobson M, Hildrew AG, Townsend CR: Multiple stressors in freshwater ecosystems. Freshwater Biol 2010, 55(Suppl):1-4

8. Strayer DL, Dudgeon D: Freshwater biodiversity conservation: recent progress and future challenges. J N Am Benthol Soc 2010, 29:344-358.
9. Balian EV, Segers H, Lévêque C, Martens K: An introduction to the freshwater animal diversity assessment (FADA) project. Hydrobiologia 2008, 595:3-8.

10. Costanza R, d'Arge R, de Groot R, Farber S, Grasso M, Hannon B, Limburg K, Naeem S, O'Neill RV, Paruelo J, Raskin RG, Sutton P, van den Belt M: The value of the world's ecosystem services and natural capital. Ecol Econ 2010, 25:3-15.

11. Holmlund CM, Hammer M: Ecosystem services generated by fish populations. Ecol Econ 1999, 29:253-268.

12. Millennium Ecosystem Assessment: Ecosystems and Human Well-Being: Current State and Trends, Volume 1. Washington, DC: Island Press; 2005.

13. Welcomme RL, Cowx IG, Coates D, Béné C, Funge-Smith S, Halls A, Lorenzen K: Inland capture fisheries. Philos Trans R Soc Lond B Biol Sci 2010, 365:2881-2896

14. Lucas MC, Baras E: Migrations of Freshwater Fishes. Oxford, UK: Blackwell Scientific Publications; 2001

15. Lucas MC, Baras E: Methods for studying spatial behaviour of freshwater fishes in the natural environment. Fish Fish 2000, 1:283-316.

16. Gibbons JW, Andrews KM: PIT tagging: simple technology at its best. Bioscience 2004, 54:447.

17. Cooke SJ, Thorstad E, Hinch SG: Activity and energetics of free-swimming fish: insights from electromyogram telemetry. Fish Fish 2004, 5:21-52.

18. Cooke SJ, Hinch SG, Lucas MC, Lutcavage M: Biotelemetry and biologging In Fisheries Techniques. 3rd edition. Edited by Zale AV, Parrish DL, Sutton TM. Bethesda, MD: American Fisheries Society; 2013:819-860.

19. Eiler JH: Tracking aquatic animals with radio telemetry. In Telemetry Techniques: A User Guide for Fisheries Research. Edited by Adams NS, Beeman JW, Eiler JH. Bethesda, MD: American Fisheries Society; 2012:163-204.

20. Breukelaar AW, bij de Vaate A, Fockens KTW: Inland migration study of sea trout (Salmo trutta) into the rivers Rhine and Meuse (The Netherlands), based on inductive coupling radio telemetry. Hydrobiologia 1998, 372:29-33.

21. Ramm DC: Electromagnetic tracking of rock lobsters (Jasus novachollandiae). Mar Freshwater Res 1980, 31:263-269.

22. Solomon DJ, Potter E: First results with a new estuarine fish tracking system. J Fish Biol 1988, 33:127-132.

23. Klimley AP, Voegeli F, Beavers SC, Le Boeuf BJ: Automated listening stations for tagged marine fishes. Mar Technol Soc J 1998, 32:94-101.

24. Holland KN, Meyer CG, Dagorn LC: Inter-animal telemetry: results from first deployment of acoustic 'business card' tags. Endang Species Res 2010, 10:287-293

25. Akamatsu T: Diving behaviour of freshwater finless porpoises (Neophocaena phocaenoides) in an oxbow of the Yangtze River, China. ICES J Mar Sci 2002, 59:438-443.

26. Hasler CT, Suski CD, Hanson KC, Cooke SJ, Philipp DP, Tufts BL: Effect of water temperature on laboratory swimming performance and natural activity levels of adult largemouth bass. Can J Zool 2009, 87:589-596.

27. Cooke SJ, Niezgoda GH, Hanson KC, Suski CD, Phelan FJS, Tinline R, Philipp DP: Use of CDMA acoustic telemetry to document 3-D positions of fish: relevance to the design and monitoring of aquatic protected areas. Mar Technol Soc J 2005, 39:31-41.

28. Brown RS, Hubert WA, Daly SF: A primer on winter, ice, and fish: what fisheries biologists should know about winter ice processes and streamdwelling fish. Fisheries 2011, 36:8-26.

29. Brown RS, Mackay WC: Spawning ecology of cut-throat trout (Oncorhynchus clarkii) in the Ram River, Alberta. Can J Fish Aquat Sci 1995, 52:983-992.

30. Cooke SJ, Thorstad EB: Is radio telemetry getting washed downstream? The changing role of radio telemetry in studies of freshwater fish relative to other tagging and telemetry technology. Am Fish S S 2012, 76:349-369.

31. Brown RS, Power G, Beltaoa S: Winter movements and habitat use of riverine brown trout, white sucker and common carp in relation to flooding and ice break-up. J Fish Biol 2001, 59:1126-1141.

32. Johnston P, Bérubé F, Bergeron NE: Development of a flatbed passive integrated transponder antenna grid for continuous monitoring of fishes in natural streams. J Fish Biol 2009, 74:1651-1661.

33. Roussel JM, Cunjak RA, Newbury R, Caissie D, Haro A: Movements and habitat use by PIT-tagged Atlantic salmon parr in early winter: the influence of anchor ice. Freshwater Biol 2004, 49:1026-1035.

34. Stasko AB, Pincock DG: Review of underwater biotelemetry, with emphasis on ultrasonic techniques. Can J Fish Aquat Sci 1977, 34:1261-1285.

35. Freund JG, Hartman KJ: Influence of depth on detection distance of lowfrequency radio transmitters in the Ohio River. N Am J Fish Manage 2002, 22:1301-1305 
36. Peters LM, Reinhardt UG, Pegg MA: Factors influencing radio wave transmission and reception: use of radiotelemetry in large river systems. N Am J Fish Manage 2008, 28:301-307.

37. Bunt CM, Cooke SJ, Philipp DP: Mobility of riverine smallmouth bass related to tournament displacement and seasonal movements. In Black Bass: Ecology Conservation and Management. Edited by Philipp DP, Ridgway MS. Bethesda, MD: American Fisheries Society; 2003:356-363.

38. Heupel MR, Semmens JM, Hobday AJ: Automated acoustic tracking of aquatic animals: scales, design and deployment of listening station arrays. Mar Freshw Res 2006, 57:1-13.

39. Zeibell CD: Ultrasonic transmitters for tracking channel catfish. The Progressive Fish-Culturist 1973, 335:28-32.

40. Bergé J, Capra H, Pella H, Steig T, Ovidio M, Bultel E, Lamouroux N Probability of detection and positioning error of a hydro acoustic telemetry system in a fast-flowing river: intrinsic and environmental determinants. Fish Res 2012, 125/126:1-13.

41. Titzler PS, McMichael GA, Carter JA: Autonomous acoustic receiver deployment and mooring techniques for use in large rivers and estuaries. N Am J Fish Manage 2010, 30:853-859.

42. Stuehrenberg L, Giorgi A, Bartlett C: Pulse-coded radio tags for fish identification. Am Fish S S 1990, 7:370-374.

43. Velle JJ, Weeks LR, Long F: An investigation of the loss mechanism encountered in propagation from a submerged fish telemetry transmitter. In 2nd International Conference of Wildlife Biotelemetry. 1979:228-237.

44. Shroyer SM, Logsdon DE: Detection distances of selected radio and acoustic tags in Minnesota lakes and rivers. N Am J Fish Manage 2009, 29:876-884

45. Aymes JC, Rives J: Detection efficiency of multiplexed passive integrated transponder antenna is influenced by environmental conditions and fish swimming behaviour. Ecol Freshw Fish 2009, 18:507-513.

46. Fisher WL, Wilkerson ML: Assessment of radio and ultrasonic telemetry system in a polyhaline reservoir. In Air and Water Management Association 90 - Annual Meeting. 1997:231-238.

47. Voegeli FA, Pincock DG: Overview of underwater acoustics as it applies to telemetry. In Underwater Biotelemetry. Edited by Baras E, Philippart JC. Liege: University of Liege; 1996:22-30.

48. Hahn L, Agostinho AA, English KK, Carosfeld J, da Câmara LF, Cooke SJ: Use of radiotelemetry to track threatened dorados Salminus brasiliensis in the upper Uruguay River, Brazil. Endang Species Res 2011, 15:103-114.

49. Cooke SJ, Bunt CM, McKinley RS: Winter residency of smallmouth bass in a thermal discharge canal: implications for tempering pump operation. N Am J Fish Manage 2000, 20:288-295.

50. Beddow TA, Deary C, McKinley RS: Migratory and reproductive activity of radio-tagged Arctic char (Salvelinus alpinus L.) in northern Labrador. Hydrobiologia 1998, 371:249-262.

51. Niezgoda G, Benfield MC, Sisak M, Anson P: Tracking acoustic transmitters by code division multiple access (CDMA) based telemetry. Hydrobiologia 2002, 483:275-286.

52. Hockersmith EE, Peterson BW: Use of the global positioning system for locating radio-tagged fish from aircraft. N Am J Fish Manage 1997, 17:457-460.

53. McCleave JD, Power JH, Rommel SA Jr: Use of radio telemetry for studying upriver migration of adult Atlantic salmon (Salmo salar). J Fish Biol 1978, 12:549-558.

54. Cato DH, Bell MJ: Ultrasonic ambient noise in Australian shallow waters at frequencies up to $200 \mathrm{kHz}$. Report no MRL-TR-91-23. Ascot Vale, Australia: Materials Research Lab; 1992.

55. Garrott RA, White GC, Bartmann RM, Weybright DL: Reflected signal bias in biotelemetry triangulation systems. J Wildlife Manage 1986, 50:747-752

56. Melnychuk MC, Christensen V: Methods for estimating detection efficiency and tracking acoustic tags with mobile transect surveys. J Fish Biol 2009, 75:1773-1794.

57. Ahlers AA, Heske EJ, Schooley RL, Mitchell MA: Home ranges and space use of muskrats Ondatra zibethicus in restricted linear habitats. Wildlife Biol 2010, 16:400-408.

58. Bridger $C$, Booth $R$ : The effects of biotelemetry transmitter presence and attachment procedures on fish physiology and behavior. Rev Fish Sci 2003, 11:13-34.

59. O'Connor CM, Gilmour KM, Arlinghaus R, Hasler CT, Philipp DP, Cooke SJ: Seasonal carryover effects following the administration of cortisol to a wild teleost fish. Physiol Biochem Zool 2010, 83:950-957.
60. Belzer W, Seibert S: A transmitter attachment method for terrestrial turtles, designed to protect the radio module from mammalian chewing. Turtle and Tortoise Newsletter 2009, 14:18-21.

61. Heupel MR, Reiss KL, Yeiser BG, Simpfendorfer CA: Effects of biofouling on performance of moored data logging acoustic receivers. Limnol Oceanogr: Methods 2008, 6:327-335.

62. Thorstad EB, Hay CJ, Næsje TF, Økland F: Movements and habitat utilisation of three cichlid species in the Zambezi River, Namibia. Ecol Freshw Fish 2001, 10:238-246.

63. Knight AE, Marancik G, Layzer JB: Monitoring movements of juvenile anadromous fish by radiotelemetry. The Progressive Fish-Culturist 1977, 39:148-150.

64. Jepsen N, Berg S: Use of winter refuges by roach tagged with miniature radio transmitters. Hydrobiologia 2002, 483:167-173.

65. Peterman WE, Crawford JA, Semlitsch RD: Productivity and significance of headwater streams: population structure and biomass of the blackbellied salamander (Desmognathus quadramaculatus). Freshwater Biol 2008, 53:347-357.

66. Schütze $\mathrm{S}$, Stein $\mathrm{H}$, Born O: Radio telemetry observations on migration and activity patterns of restocked noble crayfish Astacus astacus (L.) in the small river Sempt, north-east of Munich, Germany. Freshwater Crayfish 1999, 12:688-695.

67. Eiler $\mathrm{JH}$ : A remote satellite-linked tracking system for studying Pacific salmon with radio telemetry. Trans Amer Fish Soc 1995, 124:184-193.

68. Bjornn TC, Tolotti KR, Hunt JP, Keniry PJ, Ringe RR, Peery CA: Passage of Chinook Salmon Through the Lower Snake River and Distribution Into the Tributaries, 1991 1993: Part 1 of Final Report for Migration of Adult Chinook Salmon and Steelhead Past Dams and Through Reservoirs In the Lower Snake River and Into Tributaries. Walla Walla District, Washington: US Army Corps of Engineers; 1998.

69. Colavecchia M, Katopodis C, Goosney R, Scruton DA, McKinley RS: Measurement of burst swimming performance in wild Atlantic salmon (Salmo salar L.) using digital telemetry. Regul Rivers Res Mgmt 1998, 14:41-51.

70. Hawkins AD, MacLennan DN, Urquhart GG, Rob C: Tracking cod Gadus morhua L. in a Scottish loch. J Fish Biol 1974, 6:225-236.

71. Voegeli FA, Lacroix GL, Anderson JM: Development of miniature pingers for tracking Atlantic salmon smolts at sea. Hydrobiologia 1998, 371/372:35-46.

72. Mathes MT, Hinch SG, Cooke SJ, Crossin GT, Patterson DA, Lotto AG, Farrell AP: Effect of water temperature, timing, physiological condition, and lake thermal refugia on migrating adult Weaver Creek sockeye salmon (Oncorhynchus nerka). Can J Fish Aquat Sci 2009, 67:70-84.

73. Lacroix GL, Voegeli FA: Development of automated monitoring systems for ultrasonic transmitters. In Advances in Fish Telemetry. Edited by Moore A, Russell I. Lowestoft, UK: CEFAS; 2000:37-50.

74. Steig TW, Skalski JR, Ransom BH: Comparison of acoustic and PIT-tagged juvenile Chinook, steelhead, and sockeye salmon (Oncorhynchus spp.) passing dams on the Columbia River, USA. Aquatic telemetry: advances and applications. In Proceedings of the 5th Conference on Fish Telemetry: 9-13 June 2003; Ustica, Italy. http://www.fao.org/docrep/008/y5999e/y5999e00.htm.

75. Melnychuk MC, Welch DW, Walters CJ, Christensen V: Riverine and early ocean migration and mortality patterns of juvenile steelhead trout (Oncorhynchus mykiss) from the Cheakamus River, British Columbia. Hydrobiologia 2007, 582:55-65.

76. Teo SLH, Sandstrom PT, Chapman ED, Null RE, Brown K, Klimley AP, Block BA: Archival and acoustic tags reveal the post-spawning migrations, diving behavior, and thermal habitat of hatchery-origin Sacramento River steelhead kelts (Oncorhynchus mykiss). Environ Biol Fishes 2013, 96:175-187.

77. Hanson KC, Cooke SJ, Suski CD, Niezgoda G, Phelan FJS, Tinline R, Philipp DP: Assessment of largemouth bass (Micropterus salmoides) behavior and activity at multiple spatial and temporal scales utilizing a 3-D whole-lake ecological telemetry observatory. Hydrobiologia 2007, 582:243-256.

78. Espinoza M, Farrugia TJ, Webber DM, Smith F, Lowe CG: Testing a new acoustic telemetry technique to quantify longterm, fine-scale movements of aquatic animals. Fish Res 2011, 18:364-371.

79. Fausch KD, Torgersen CE, Baxter CV, Li HW: Landscapes to riverscapes: bridging the gap between research and conservation of stream fishes. Bioscience 2002, 52:483-498.

80. Laughton R, Smith GW: The relationship between the date of river entry and the estimated spawning position of adult Atlantic salmon (Salmo salar L.) in two Scottish major east coast rivers. In Wildlife Telemetry: Remote Monitoring and Tracking Of Animals. Edited by Priede IG, Swift SM. New York: Ellis Horwood; 1992:423-433. 
81. Perry GL, Bond NR: Spatially explicit modeling of habitat dynamics and fish population persistence in an intermittent lowland stream. Ecol Appl 2009, 19:731-746.

82. Prentice EF, Flagg TA, McCutcheon CA: Feasibility of using implantable passive integrated (PIT) tags in salmonids. Am Fish S S 1990, 7:317-322.

83. Prentice EF, Flagg TA, McCutcheon S: PIT tag monitoring systems for hydroelectric dams and fish hatcheries. Am Fish S S 1990, 7:323-334.

84. Prentice EF, Flagg TA, McCutcheon CA, Brastow DF, Cross DC: Equipment, methods and automated data-entry station for PIT tagging. Am Fish S S 1990, 7:335-340.

85. Castro-Santos T, Haro A, Walk S: A passive integrated transponder (PIT) tag system for monitoring fishways. Fish Res 1996, 28:253-261.

86. Barbin Zydlewski G, Haro A, Whalen KG, McCormick SD: Performance of stationary and portable passive transponder detection systems for monitoring of fish movements. J Fish Biol 2001, 58:1471-1475.

87. Bolland JD, Cowx IG, Lucas MC: Dispersal and survival of stocked cyprinids in a small English river: comparison with wild fishes using a multi-method approach. J Fish Biol 2009, 74:2313-2328.

88. Barbin Zydlewski G, Horton G, Dubreuil T, Letcher B, Casey S, Zydlewski J: Remote monitoring of fish in small streams a unified approach using PIT tags. Fisheries 2006, 31:492-502.

89. Jorgensen T, Ovredal JT, Huse I, Spedicato MT, Lembo G, Marmulla G: A new pass-through PIT tag detection system for marine use. In Aquatic Telemetry: Advances and Applications. Proceedings of the Fifth Conference on Fish Telemetry. Edited by COISPA Tecnologia and RicercaUstica. Italy: Food and Agriculture Organization of the United Nations; 2005:9-13.

90. Bubb DH, Lucas MC, Thom TJ, Rycroft P: The potential use of PIT telemetry for identifying and tracking crayfish in their natural environment. Hydrobiologia 2002, 483:225-230.

91. Bubb DH, Thom TJ, Lucas MC: Movement patterns of the invasive signal crayfish determined by PIT telemetry. Can J Zoolog 2006, 84:1202-1209.

92. Cucherousset J, Marty P, Pelozuelo L, Roussel JM: Portable PIT detector as a new tool for non-disruptively locating individually tagged amphibians in the field: a case study with Pyrenean brook salamanders (Calotriton asper). Wildl Res 2009, 35:780-787.

93. Good TP, McClure MM, Sandford BP, Barnas KA, Marsh DM, Ryan BA, Casillas E: Quantifying the effect of Caspian tern predation on threatened and endangered Pacific salmon in the Columbia River estuary. Endang Species Res 2007, 3:11-21.

94. Eiler $\mathrm{JH}$ : Radio transmitters used to study salmon in glacial rivers. Am Fish S Sm 1990, 7:364-369.

95. Lucas MC, Johnstone ADF, Priede IG: Use of physiological telemetry as a method of estimating metabolism in fish in the natural environment. Trans Am Fish Soc 1993, 122:822-833.

96. Cooke SJ, Hinch SG, Wikelski M, Andrews RD, Wolcott TG, Butler PJ: Biotelemetry: a mechanistic approach to ecology. Trends Ecol Evol 2004, 19:334-343.

97. Oswald RL: The use of telemetry to study light synchronization with feeding and gill ventilation rates in Salmo trutta. J Fish Biol 1978, 13:729-739.

98. Sayre PD: A Radiotelemetry System for Monitoring the Activity Levels of Free Swimming Fish. Canada: MSc Thesis. University of New Brunswick; 1978.

99. Ross LG, Watts W, Young AH: An ultrasonic biotelemetry system for the continuous monitoring of tail-beat rate from free-swimming fish. J Fish Biol 1981, 18:479-490.

100. Priede IG: Heart rate telemetry from fish in the natural environment. Comp Biochem Physiol 1983, 76A:515-524.

101. Smith EN: Multichannel temperature and heart rate radio-telemetry transmitter. J Appl Physiol 1974, 36:252-255.

102. Nomura NA, Ibaraki T: Electrocardiogram of the rainbow trout and its radio transmission. Jap J Vet Sci 1969, 31:135-137.

103. Armstrong JD, Lucas MC, Priede IG, De Vera L: An acoustic telemetry system for monitoring the heart rate of pike, Esox lucius $L$., and other fish in their natural environment. J Exp Biol 1989, 143:549-552.

104. Clark TD, Hinch SG, Taylor BD, Frappell PB, Farrell AP: Sex differences in circulatory oxygen transport parameters of sockeye salmon (Oncorhynchus nerka) on the spawning ground. J Comp Physiol B 2009, 179:663-671.

105. Clark TD, Sandblom E, Hinch SG, Patterson DA, Frappell PB, Farrell AP: Simultaneous biologging of heart rate and acceleration, and their relationships with energy expenditure in free-swimming sockeye salmon (Oncorhynchus nerka). J Comp Physiol B 2010, 180:673-684.
106. Kawabe R, Nashimoto K, Hiraishi T, Naito Y, Sato K: A new device for monitoring the activity of freely swimming flatfish, Japenese flounder Paralichthys olivaceus. Fisheries Sci 2003, 69:3-10

107. Wilson RP, Shepard ELC, Liebsch N: Prying into the intimate details of animal lives: use of a daily diary on animals. Endang Species Res 2008, 4:123-137.

108. Shepard ELC, Wilson RP, Quintana F, Laich AG, Liebsch N, Albareda DA Halsey LG, Gleiss A, Morgan DT, Myers AE, Newman C, Macdonald DW: Identification of animal movement patterns using tri-axial accelerometry. Endang Species Res 2008, 10:47-60.

109. Warner EJ, Quinn TP: Horizontal and vertical movements of telemetered rainbow trout (Oncorhynchus mykiss) in Lake Washington. Can J Zool 1995, 73:146-153.

110. Manning B, Grigg GC: Basking behaviour is not of thermoregulatory significance to the 'basking' freshwater turtle Emydura signata. Copeia 1997:579-584.

111. Beeman JW, Haner PV, Maule AG: Evaluation of a new miniature pressuresensitive radio transmitter. N Am J Fish Manage 1988, 18:458-464.

112. Priede IG: An ultrasonic salinity telemetry transmitter for use on fish in estuaries. Biotelem Patient Monit 1982, 9:1-9.

113. Priede IG, Solbe JFLG, Nott JE: Short communication an acoustic oxygen telemetry transmitter for the study of exposure of fish to variations in environmental dissolved oxygen. J Exp Biol 1988, 140:563-567.

114. Seebacher F, Elsey RM, Trosclair PL III: Body temperature null distributions in reptiles with nonzero heat capacity: seasonal thermoregulation in the American alligator (Alligator mississippiensis). Physiol Biochem Zool 2003, 76:348-359.

115. Grayson $\mathrm{KL}$, Dorcas ME: Seasonal temperature variation in the painted turtle (Chrysemys picta). Herpetologica 2004, 60:325-336.

116. Donaldson MR, Cooke SJ, Patterson DA, Hinch SG, Robichaud D, Hanson KC, Olsson I, Crossin GT, English KK, Farrell AP: Limited behavioural thermoregulation by adult up-river migrating sockeye salmon (Oncorhynchus nerka) in the Lower Fraser River mainstem, British Columbia. Can J Zool 2009, 87:480-490.

117. Frank TH: Telemetering the electrocardiogram of free swimming Salmo irideus. IEEE Trans Biomed Eng 1968, 2:111-114.

118. Priede IG, Young AH: The ultrasonic telemetry of cardiac rhythms of wild brown trout (Salmo truffa L.) as an indicator of bio-energetics and behaviour. J Fish Biol 1977, 10:299-318.

119. Klimley AP: Highly directional swimming by scalloped hammerhead sharks, Sphyrna lewini, and subsurface irradiance, temperature, bathymetry, and geomagnetic field. Mar Biol 1993, 117:1-22

120. Ebner BC: Preface. Tagging for telemetry of freshwater fauna. Mar Freshw Res 2009, 60:281-283.

121. Cooke SJ, Woodley C, Eppard MB, Brown RS, Nielsen JL: Advancing the surgical implantation of electronic tags in fish: a gap analysis and research agenda based on a review of trends in intracoelomic tagging effects studies. Rev Fish Biol Fish. 2011, 21:127-151.

122. Doody JS, Roe J, Mayes P, Ishiyama L: Telemetry tagging methods for some freshwater reptiles. Mar Freshw Res 2009, 60:293-298.

123. Hart LG, Summerfelt RC: Surgical procedures for implanting ultrasonic transmitters into flathead catfish (Pylodictis olivaris). Trans Amer Fish Soc 1975, 104:56-59.

124. Jepsen N, Koed A, Thorstad EB, Baras E: Surgical implantation of telemetry transmitters in fish: how much have we learned? Hydrobiologia 2002, 483:239-248.

125. Mosley CAE: Anesthesia and analgesia in reptiles. Semin Avian Exot Pet Med 2005, 14:243-262

126. Ross LG, Ross B: Anaesthetic and Sedative Techniques for Aquatic Animals. Oxford: Blackwell Scientific Publications; 1999.

127. Franklin CE, Read MA, Kraft PG, Liebsch N, Irwin SR, Campbell HA: Remote monitoring of crocodilians: implantation, attachment and release methods for transmitters and data-loggers. Mar Freshw Res 2009, 60:284-292.

128. Whitty JM, Morgan DL, Peverell SC, Thorburn DC, Beatty SJ: Ontogenetic depth partitioning by juvenile freshwater sawfish (Pristis microdon: Pristidae) in a riverine environment. Mar Freshw Res 2009, 60:306-316.

129. Broadhurst BT, Ebner BC, Clear RC: Radio-tagging flexible-bodied fish: temporary confinement enhances radio-tag retention. Mar Freshw Res 2009, 60:356-360.

130. Summerfelt RC, Mosier D: Transintestinal expulsion of surgically implanted dummy transmitters by channel catfish. Trans Am Fish Soc $1984,113: 760-766$. 
131. Broadhurst BT, Ebner BC, Clear RC: Effects of radio-tagging on two-year -old, endangered Macquarie perch (Macquaria australasica: Percichthyidae). Mar Freshw Res 2009, 60:341-345.

132. Baras E, Jeandrain D: Evaluation of surgery procedures for tagging eel Anguilla (L.) with biotelemetry transmitters. Hydrobiologia 1998, 371/372:107-111.

133. Mulcahy DM: Surgical implantation of transmitters into fish. ILAR J 2003, 44:295-306.

134. Cooke SJ, Hinch SG, Farrell AP, Patterson DA, Miller-Saunders K, Welch DW, Donaldson MR, Hanson KC, Crossin GT, Mathes MT, Lotto AG, Hruska KA, Olsson IC, Wagner GN, Thomson R, Hourston R, English KK, Larsson S, Shrimpton JM, Van der Kraak G: Developing a mechanistic understanding of fish migrations by linking telemetry with physiology, behavior, genomics and experimental biology: an interdisciplinary case study on adult Fraser River sockeye salmon. Fisheries 2008, 33:321-338.

135. Cunjak RA, Roussel JM, Gray MA, Dietrich JP, Cartwright DF, Munkittrick KR, Jardine TD: Using stable isotope analysis with telemetry or markrecapture data to identify fish movement and foraging. Oecologia 2005, 2005(144):636-646.

136. Östergren J, Nilsson J, Lundqvist H: Linking genetic assignment tests with telemetry enhances understanding of spawning migration and homing in sea trout Salmo trutta L. Hydrobiologia 2012, 1:123-134.

137. Nielsen C, Aarestrup K, Nørum U, Madsen SS: Future migratory behaviour predicted from premigratory levels of gill $\mathrm{Na}^{+} / \mathrm{K}^{+}$-ATPase activity in individual wild brown trout (Salmo trutta). J Exp Biol 2004, 207:527-533.

138. Sato A, Ueda H, Fukaya M, Kaeriyama M, Zohar Y, Urano A, Yamauchi K: Sexual differences in homing profiles and shortening of homing duration by gonadotropin-releasing hormone analog implantation in lacustrine sockeye salmon (Oncorhynchus nerka) in Lake Shikotsu. Zoolog Sci 1997, 14:1009-1014.

139. Brodersen J, Nilsson PA, Hansson LA, Skov C, Brönmark C: Conditiondependent individual decision-making determines cyprinid partial migration. Ecology 2008, 89:1195-1200.

140. Crossin GT, Hinch SG, Cooke SJ, Welch DW, Batten SD, Patterson DA, Van Der Kraak G, Shrimpton JM, Farrell AP: Behaviour and physiology of sockeye salmon homing through coastal waters to a natal river. Mar Biol 2007, 152:905-918.

141. Ueda H, Kaeriyama M, Mukasa K, Urano A, Kudo H, Shoji T, Tokumitsu Y, Yamauchi K, Kurihara K: Lacustrine sockeye salmon return straight to the natal area from open water using both visual and olfactory cues. Chem Senses 1998, 23:207-212.

142. Ueda H: Physiological mechanisms of imprinting and homing migration in Pacific salmon Oncorhynchus spp. J Fish Biol 2012, 81:543-558.

143. Miller KM, Li S, Kaukinen KH, Ginther N, Hammill E, Curtis JMR, Patterson DA, Sierocinski T, Donnison L, Pavlidis P, Hinch SG, Hruska KA, Cooke SJ, English KK, Farrell AP: Genomic signatures predict migration and spawning failure in wild Canadian salmon. Science 2011, 331:214-217.

144. Nestler JM, Goodwin RA, Smith DL, Anderson JJ, Li S: Optimum fish passage and guidance designs are based in the hydrogeomorphology of natural rivers. River Res Appl 2008, 24:148-168.

145. Rogers KB, White GG: Analysis of movement and habitat use from telemetry data. In Analysis and Interpretation of Freshwater Fisheries Data. Edited by Guy C, Brown M. Bethesda, Maryland: American Fisheries Society; 2007:625-676

146. Burnham KP, Anderson DR, White GC, Brownie C, Pollock KH: Design and analysis methods for survival experiments based on release-recapture, American Fisheries Society Monographs, Volume 5. Bethesda MD: American Fisheries Society; 1987.

147. Skalski JR, Smith S, Iwamoto RN, Williams JG, Hoffman A: Use of passive integrated transponder tags to estimate survival of migrant juvenile salmonids in the Snake and Columbia rivers. Can J Fish Aquat Sci 1998, 55:1484-1493.

148. Castro-Santos T, Haro A: Quantifying migratory delay: a new application of survival analysis methods. Can J Fish Aquat Sci 2003, 60:986-996.

149. Eiler JH, Masters MA: A database-GIS mapping program for summarizing salmon telemetry data for the Yukon River basin. In Biotelemetry 15: Proceedings of the 15th International Symposium on Biotelemetry. Juneau, Alaska USA. Edited by Eiler JH, Alcorn DJ, Neuman MR. Wageningen; International Society on Biotelemetry; 2000:138.

150. Flavelle LS, Ridgway MS, Middel TA, McKinley RS: Integration of acoustic telemetry and GIS to identify potential spawning areas for lake trout (Salvelinus namaycush). Hydrobiologia 2002, 483:137-146.
151. Hodder KH, Masters JEG, Beaumont WRC, Gozlan RE, Pinder AC, Knight CM, Kenward RE: Techniques for evaluating the spatial behaviour of river fish. Hydrobiologia 2007, 582:257-269.

152. Crook D: Is the home range concept compatible with the movements of two species of lowland river? J Anim Ecol 2004, 73:353-366.

153. Crook DA: Movements associated with home-range establishment by two species of lowland river fish. Can J Fish Aquat Sci 2004, 61:2183-2193.

154. Knight CM, Kenward RE, Gozlan RE, Hodder KH, Walls SS, Lucas MC: Homerange estimation within complex restricted environments: importance of method selection in detecting seasonal change. Wild Res 2009, 36:213-224.

155. Hogan Z, Heng K, Zalinge N: Underwater biotelemetry to study fish migrations in the Mekong River. Mekong Fish Catch Culture 2002, 7:9-13.

156. Hocutt $\mathrm{CH}$, Seibold SE, Jesien RV: Potential use of biotelemetry in tropical continental waters. Revue d'hydrobiologie tropicale 1994, 27:77-95.

157. Baras E, Benech V, Marmulla G: Outcomes of a pilot fish telemetry workshop for developing countries. Hydrobiologia 2002, 483:9-11.

158. Pais S, Symonds J: Data storage on a RFID tag for a distributed system. International Journal of UbiComp 2011, 2:26-39.

159. Mitson RB, Storeton-West TJ: A transponding acoustic fish tag. Radio Electronic Engineering 1971, 41:483-489.

160. Erickson DL, Kahnle A, Millard MJ, Mora EA, Bryja M, Higgs A, Mohler J, DuFour M, Kennery G, Sweka J, Pikitch EK: Use of pop-up satellite archival tags to identify oceanic-migratory patterns for adult Atlantic sturgeon, Acipenser oxyrinchus oxyrinchus Mitchell, 1815. J Appl Ichthyol 2011, 27:356-365

doi:10.1186/2050-3385-1-5

Cite this article as: Cooke et al:: Tracking animals in freshwater with electronic tags: past, present and future. Animal Biotelemetry 2013 1:5

\section{Submit your next manuscript to BioMed Central and take full advantage of:}

- Convenient online submission

- Thorough peer review

- No space constraints or color figure charges

- Immediate publication on acceptance

- Inclusion in PubMed, CAS, Scopus and Google Scholar

- Research which is freely available for redistribution
C Biomed Central 